\title{
Are Androgens Valuable in Management of Diabetes?
}

\author{
Sopiko Kandelaki ${ }^{2}$, Keti Tsomaia ${ }^{1,2}$, Salome Kordzaia ${ }^{3}$, Natia Chkheidze ${ }^{2}$, Dimitri Kordzaia ${ }^{1,2}$ and Manana \\ Kakabadze ${ }^{1,2 *}$ \\ ${ }^{1}$ AI Natishvili Institute of Morphology, Georgia \\ ${ }^{2}$ Ivane Javakhishvili Tbilisi State University, Georgia \\ ${ }^{3}$ David Tvildiani Medical University, Georgia
}

Submission: June 27, 2017;Published: July 10, 2017

*Corresponding author: Manana Kakabadze, Assistant Professor of Anatomy Department, Al. Natishvili Institute of Morphology, Ivane Javakhishvili Tbilisi State University, Georgia, Tel: +995598197133; Email: manana.kakabadze@tsu.ge

\begin{abstract}
The Influence of androgens on diabetes mellitus is a subject of extensive discussion. Testosterone effect in clinical trials commonly is evaluated in patients with diabetes type 2. In addition, the studies conducted on experimental models of diabetes (alloxan- and streptozotocininduced diabetes) also showed positive effects of androgen. Considering that experimental diabetes is more in line with diabetes type 1 , it can be assumed that male sex hormone positively effects both types of diabetes. However, its influence may be realized by different pathways. Therefore, research of the opportunity of treatment of the various forms of diabetes with androgens, represents the active scientific and practical feature, which is waiting for the final verdict.
\end{abstract}

Keywords: Diabetes mellitus; Testosterone; Experimental diabetes

\section{Introduction}

It is established, that the testosterone deficiency promotes the development of the metabolic syndrome, insulin resistance, type 2 diabetes mellitus, hyperglycemia, as well as dyslipidemia and arterial hypertension, which, in turn, increases the risk of vascular diseases [1-7]. Conversely, in the case of high level of testosterone, insulin resistance decreases and the risk of development of diabetes is significantly reduced [8,9]. In addition, the decrease in the index of insulin resistance is in higher correlation with free testosterone than with the total testosterone $[5,10,11]$. Supplementation of testosterone in males with diabetes mellitus reduces the level of glucose in fasting and after eating, as well as level of glycosylated hemoglobin $[12,13]$ and allows to reduce the dose of the insulin in insulin-dependent patients $[3,14]$.

In this background, it is interesting to note that the results of several studies deny the statistically significant difference between the patients with metabolic syndrome and type 2 diabetes, treated with testosterone and without it. This indicates the need to continue research in this direction $[15,16]$.

\section{Discussion}

It is confirmed that obesity and associated with it hyperinsulinemia stimulates the formation of testosterone, but suppresses the synthesis of sex hormone binding globulin (SHBG) and thus reduces the number of circulating testosterone $[17,18]$. Low levels of testosterone and SHBG are considered as a predictors of the development of metabolic syndrome and diabetes mellitus type $2[19,20]$ and vice versa [21]. Insulin resistance in the condition of the androgen deficiency is likely to be associated with the changes of sensitivity of the skeletal muscle to insulin. Castration of rats causes the expressed insulin resistance in skeletal muscles, which is completely restored by treatment with physiologic doses of testosterone [22]. Testosterone, except the effect of sensitivity to insulin, can directly influence on pancreatic $\beta$-cells [23]. Following the androgen suppression therapy expressed hyperglycemia and $\beta$-cells function failure are revealed [24], while streptozotocininduced early apoptotic damage of $\beta$-cells in castrated animals is prevented by testosterone replacement therapy [25]. 


\section{Current Research in Diabetes \& Obesity Journal}

Testosterone acts through the androgen receptor (AR), which represents a ligand-activated transcription factor. It was shown, that in male mice with reduced number of AR in $\beta$-cells, as well as on human cultures, these receptors play an important role in testosterone potentiation of glucose-stimulated insulin secretion (GSIS). The pathway is based on the icrease of the cAMP concentration in the $\beta$-cells and the activation of protein kinase A (PKA), which, in turn, increases the GLP-1 (glucagonlike peptide-1) effect. This finding may have important clinical and pharmacological value for the prevention of type 2 diabetes in elderly men [26]. Glucose homeostasis was studied in 12 weeks male mice lacking AR in $\beta$ cells ( $\beta$ ARKO). This is the age, which is followed by the development of the delayed obesity and insulin resistance in mice, backed by the total (or partial) deficit of AR. During 9 weeks, in the conditions of metabolic stress caused by the western diet, the $\beta$ ARKO-/y mice showed reduced insulin concentration and hyperglycemia both, after fasting as well as after feeding, unlike the control group mice. Thus, it has been confirmed that in the mice with a deficiency of AR in $\beta$-cells, the tendency to insulin deficiency is revealed,while western diet is followed by GSIS reduction and development of tolerance to glucose, despite the fact that the number of $\beta$-cellsdoes not change [26].

It is important that insulinotropic function of the AR is revealed in the human Langerhans islets in case of the physiological concentration of testosterone. It proves that testosterone is important for normal GSIS in males. Lack of androgen causes GSIS deficiency and creates favorable conditions (disposition) for the development of the type 2 diabetes mellitus. Decreasing of glucose concentration after testosterone supplementation also can be explained by the fact, that testosterone acting through the AR of liver cells promotes the synthesis of m-RNA of insulin receptors in hepatocytes, which leads to increased sensitivity of hepatocytes toward Insulin. In this condition the minimal concentration of insulin is enough to stimulate the glucose utilization by the liver cells $[3,27,28]$. In contrast to males, the lower number of AR in the $\beta$-cells of females does not change GSIS [29]. The reason is that, apparently, androgen concentrations in serum and tissues of female rats is less than needed to activate the androgen receptors [30]. As it was noted, high levels of testosterone in male are correlated with increased sensitivity to insulin. In addition, aromatization of testosterone $17 \mathrm{~b}$ to/into estrodiol (E2) is important for energetic homeostasis in males. In the castrated male rodents, treated with pure androgen-DHT, which is not transfered into E2, is developed obesity, unlike the rodents treated with testosterone. This indicates that restoration of fat after the castration is caused by the transformation of testosterone into E2, which influences estrogen receptors (ER). This observation is confirmed by the data in which the marked increase in E2 concentration paralleled the decrease in the testosterone concentration in alloxan diabetes model [28,31,32]. Following the $200 \mathrm{mg} / \mathrm{kg}$ intraperitoneal injection of Alloxan
toWistar male rats [33, 34], just like after $50 \mathrm{ml} / \mathrm{l}$ intraperitoneal injection Streptozotocin (STZ) to Sprague-Dawley female rats, there were found necrotic $\beta$-cells in Langerhans islets. The degenerative changes with lower intensity were found in epithelial cells of the liver and kidney tubules. The alloxan or STZ injection in adult rats promotes the development of severe and irreversible diabetes, which is very similar to type 1 diabetes $[28,35-37]$. $\beta$-cell death is the last phase of its damage in experimental diabetes and can be expressed with the necrosis or caspase dependent apoptosis [37].

Insuline and glucagone have opposite effects on glucose homeostasis in the liver. Low level of insulin and high level of glucagon in the state of hunger promotes gluconogenesis and glycogenolysis in the liver that prevents the development of hypoglycemia. Thus, the fasting glucose level is determined by liver generated glucose level. After eating, glucose is the major factor which promotes insulin synthesis in $\beta$-cells and causes its secretion. Synthesized insulin interacts with insulin receptor in peripheral tissues (in skeletal muscles and fatty tissues), causing a number of intracellular reactions that promote glucose absorption and utilization of postprane glucose, thus maintaining glucose homeostasis $[38,39]$. In case of type 2 diabetes mellitus, $\beta$-cells lose their ability to respond adequately to peripheral insulin-resistance and demand for increase of insulin secretion. The increased amount of glucose in the blood promotes the secretion of pro-inflammatory cytokines from $\beta$-cells, which leads to the activation of mononuclear cells and the increased production of local cytokines. These pathological inflammation results in the progression of $\beta$-cells dysfunction and leads to their death. Male patients with type 2 diabetes mellitus, who demonstrate low levels of testosterone, can improve their health by treatment with testosterone. Such a conclusion has been taken as a result of randomized, double-blind, placebocontrolled study [40].

It should be noted that the majority of clinical trials study estrogen effect in diabetes type 2 . In addition, studies conducted on experimental models of diabetes (alloxan- and STZ-induced diabetes), also confirms the positive effects of androgen. Considering that experimental diabetes is more in line with diabetes type 1 , it can be assumed that male sex hormone positively affects not only diabetes type 2 , but also diabetes type 1. The first positive clinical observations in this regard, which confirm the necessity to continue studies, have appeared [41].

\section{Conclusion}

Analysis of those studies, which examine the general mechanism of the action of androgens in "patho- and sanogenesis" of type 1 and type 2 diabetes, gives the basis to conclude that adding androgens may influence in various ways on the different disorders caused by diabetes. Therefore, research of the possibility of treatment of the various forms of diabetes with androgens, represents the active scientific and practical feature, which is waiting for the final verdict. 


\section{Current Research in Diabetes \& Obesity Journal}

\section{References}

1. Oh JY, Barrett-Connor E, Wedick NM, Wingard DL (2002) Endogenous sex hormones and the development of type 2 diabetes in older men and women: the Rancho Bernardo study. Diabetes Care 25(1): 55-60.

2. Corona G, Mannucci E, Petrone L, Ricca V, Balercia G, et al. (2006) Association of hypogonadism and type II diabetes in men attending an outpatient erectile dysfunction clinic. Int J Impot Res 18(2): 190-197.

3. Kapoor D, Goodwin E, Channer KS, Jones TH (2006) Testosterone replacement therapy improves insulin resistance, glycaemic control, visceral adiposity and hypercholesterolaemia in hypogonadal men with type 2 diabetes. Eur J Endocrinol 154(6): 899-906.

4. Fukui M, Soh J, Tanaka M, Kitagawa Y, Hasegawa G, Yoshikawa T, et al (2007) Low serum testosterone concentration in middle-aged men with type 2 diabetes. Endocr J 54(6): 871-877.

5. Selvin E, Feinleib M, Zhang L, Rohrmann S, Rifai N, et al. (2007) Androgens and diabetes in men. Diabetes Care 30: 234-238.

6. Stanworth RD, Jones TH (2009) Testosterone in obesity, metabolic syndrome and type 2 diabetes. Front Horm Res 37: 74-90.

7. Yeap BB, Hyde Z, Almeida OP, Norman PN, Chubb SA. P, et al. (2009) Lower testosterone levels predict incident stroke and transient ischemic attack in older men. J Clin Endocrinol Metab 94(7): 23532359.

8. Ding EL, Song Y, Malik VS, Liu S (2006) Sex differences of endogenous sex hormones and risk of type 2 diabetes: a systematic review and meta-analysis. JAMA 295(11): 1288-1299.

9. Lage MJ, Barber BL, Markus RA (2007) Association between androgendeprivation therapy and incidence of diabetes among males with prostate cancer. Urology $70(6): 1104-1108$.

10. Rhoden EL, Ribeiro EP, Teloken C, Souto CA (2005) Diabetes mellitus is associated with subnormal serum levels of free testosterone in men. BJU Int 96(6): 867-870.

11. Basaria S, Muller DC, Carducci MA, Egan J, Dobs AS (2006) Hyperglycemia and insulin resistance in men with prostate carcinoma who receive androgen-deprivation therapy. Cancer 106(3): 581-588.

12. Boyanov MA, Boneva Z, Christov VG (2003) Testosterone supplementation in men with type 2 diabetes, visceral obesity and partial androgen deficiency. Aging Male 6(1): 1-7.

13. Ho CH, Yu HJ, Wang CY, Jaw FS, Hsieh JT, et al. (2013) Prediabetes is associated with an increased risk of testosterone deficiency, independent of obesity and metabolic syndrome. PLoS ONE 8(9): e74173

14. Naharci MI, Pinar M, Bolu E, Olgun A (2007) Effect of testosterone on insulin sensitivity in men with idiopathic hypogonadotropic hypogonadism. Endocr Pract 13(6): 629-635.

15. Gianatti EJ, Dupuis P, Hoermann R, Strauss BJ, Wentworth JM, et al. (2014) Effect of testosterone treatment on glucose metabolism in men with type 2 diabetes: a randomized controlled trial. Diabetes care 37(8): 2098-2107.

16. Grossmann M, Hoermann R, Wittert G, Yeap BB (2015) Effects of testosterone treatment on glucose metabolism and symptoms in men with type 2 diabetes and the metabolic syndrome: A systematic review and meta-analysis of randomized controlled clinical trials. Clin Endocrinol 83(3): 344-351.

17. Kaufman JM, Vermeulen A (2005) The decline of androgen levels in elderly men and its clinical and therapeutic implications. Endoc Rev 26(6): 833-876.
18. Eckel RH, Grundy SM, Zimmet PZ (2005) The metabolic syndrome Lancet 365(9468): 1415-1428.

19. Laaksonen DE, Niskanen L, Punnonen K, Nyyssönen K, Tuomainen TP, et al. (2004) Testosterone and sex hormone-binding globulin predict the metabolic syndrome and diabetes in middle-aged men. Diabetes Care 27(5): 1036-1041.

20. Haring R, olzke HV, Felix SB, Schipf S, Dorr M, et al., (2009) Prediction of metabolic syndrome by low serumtestosterone levels inmen: results from the study of health in Pomerania. Diabetes 58(9): 2027-2031.

21. Muller M, Grobbee DE, den Tonkelaar I, Lamberts SW, van der Schouw YT (2005) Endogenous sex hormones and metabolic syndrome in aging men. J Clin Endocrinol Metab 90(5): 2618-2623.

22. Navarro G, Allard C, Xu W, Mauvais-Jarvis F (2015) The role of androgens in metabolism, obesity, and diabetes in males and females. Obesity 23(4): 713-719.

23. Mauvais-Jarvis F (2016) Role of Sex Steroids in $\beta$ cell function, growth, and survival. Trends Endocrin Metab 27(12): 844-855.

24. Inaba M, Otani Y, Nishimura K, Takaha N, Okuyama A, et al. (2005) Marked hyperglycemia after androgen-deprivation therapy for prostate cancer and usefulness of pioglitazone for its treatment. Metabolism 54(1): 55-59.

25. Morimoto S, Mendoza-Rodrı́guez CA, Hiriart M, Larrieta ME, Vital P, et al. (2005) Protective effect of testosterone on early apoptotic damage induced by streptozotocin in rat pancreas. J Endocrinol 187(2): 217224.

26. Navarro G, Xu W, Jacobson DA, Wicksteed B, Allard C, et al. (2016) Extranuclear actions of the androgen receptor enhance glucosestimulated insulin secretion in the male. Cell metab 23(5): 837-851.

27. Sato K, Iemitsu M, Aizawa K, Ajisaka R (2008) Testosterone and DHEA activate the glucose metabolism-related signaling pathway in skeletal muscle. Am J Physiol Endocrinol Metab 294(5): E961-E968.

28. Didebulidze N, Kandelaki S, Kakabadze M, Kordzaia S, Kordzaia D, et al. (2017) Effect of Methyltrienolone on the Metabolic Disorders in Rat Model of Alloxan-Induced Diabetes. ESJ 31: 13(15).

29. Visakorpi T, Hyytinen E, Koivisto P, Tanner M, Keinänen R, et al. (1995) In vivo amplification of the androgen receptor gene and progression of human prostate cancer. Nat Genet 9(4): 401-406.

30. Mauvais-Jarvis F (2011) Estrogen and androgen receptors: regulators of fuel homeostasis and emerging targets for diabetes and obesity. Trends Endocrinol Metab 22(1): 24-33.

31. Hayes FJ, Seminara SB, DeCruz S, Boepple PA, Crowley Jr WF (2000) Aromatase Inhibition in the Human Male Reveals a Hypothalamic Site of Estrogen Feedback. J Clin Endocrinol Metab 85(9): 3027-3035.

32. Hayes FJ, DeCruz S, Seminara SB, Boepple PA, Crowley WF (2001) Differential regulation of gonadotropin secretion by testosterone in the human male: Absence of a negative feedback effect of testosterone on follicle-stimulating hormone secretion. J Clin Endocrinol Metab 86(1): 53-58.

33. Latsabidze I, Janberidze E, Kakabadze M, Didebulidze N, Machavariani $\mathrm{T}$ (2016) The influence of plaferon LB on regenerative processes in the pancreas in an alloxan-induced diabetes rat model. Transl and Clin Med - Geo Med J 1(2): 4-10.

34. Kandelaki S, Didebulidze N, Kakabadze M, Kordzaia S, Relat JM, et al (2017) Methyltrienolone influences on the androgen receptors and DNA\&RNA synthesis in the liver cells of male rats with alloxan-induced diabetes. Transl and Clin Med - Geo Med J 2(1): 10-13. 


\section{Current Research in Diabetes \& Obesity Journal}

35. Portha B, Levacher C, Picon L, Rosselin G (1974) Diabetogenic effect of streptozotocin in the rat during the perinatal period. Diabetes 23(11): 889-895.

36. Wilson GL, Leiter EH (1990) Streptozotocin interactions with pancreatic $\beta$ cells and the induction of insulin-dependent diabetes. Curr Top Microbiol Immunol 156: 27-54.

37. Haligur M, Topsakal S, Ozmen O (2012) Early degenerative effects of diabetes mellitus on pancreas, liver, and kidney in rats: an immunohistochemical study. J Diabetes Res, pp. 1s10.

38. Vinay Kumar, Abul Abbas, Jon Aster (2017) Robbins Basic Pathology E-book. Elsevier Health Scientes, (10 ${ }^{\text {th }}$ edn) Chapter 20.
39. Rovira-Llopis S, Bañuls C, De Marañon AM, Diaz-Morales N, Jover A, et al. (2017) Low testosterone levels are related to oxidative stress, mitochondrial dysfunction and altered subclinical atherosclerotic markers in type 2 diabetic male patients. Free Radic Biol Med 108: 155-162.

40. http://www.medicalnewstoday.com/articles/303291.php

41. Saad F, Gooren L (2009) The role of testosterone in the metabolic syndrome: a review. J Steroid Biochem Mol Biol 114(1-2): 40-43.

\section{Your next submission with Juniper Publishers} will reach you the below assets

- Quality Editorial service

- Swift Peer Review

- Reprints availability

- E-prints Service

- Manuscript Podcast for convenient understanding

- Global attainment for your research

- Manuscript accessibility in different formats

( Pdf, E-pub, Full Text, Audio)

- Unceasing customer service

Track the below URL for one-step submission https://juniperpublishers.com/online-submission.php 